Notre Dame Law School

NDLScholarship

Natural Law Forum

$1-1-1957$

\title{
Suggestions for Clarifying Natural Law
}

Jacques Leclercq

Follow this and additional works at: http://scholarship.law.nd.edu/nd_naturallaw_forum

Part of the Law Commons

\section{Recommended Citation}

Leclercq, Jacques, "Suggestions for Clarifying Natural Law" (1957). Natural Law Forum. Paper 19.

http://scholarship.law.nd.edu/nd_naturallaw_forum/19

This Article is brought to you for free and open access by NDLScholarship. It has been accepted for inclusion in Natural Law Forum by an authorized administrator of NDLScholarship. For more information, please contact lawdr@nd.edu. 
Jacques Leclercq

There would SEem, at first blush, to be no concept more traditional, more stable, or more solidly established than that of natural law. Its history has been written a score of times, and shows it to be as old as the notions of human rights and dignity. Perhaps in the Orient, where men have always lived under despotic regimes, there is no such notion, at least in the main streams of thought. Yet, whenever a historian looks closely enough at any culture, he is likely to find some trace of almost any human institution. Man is everywhere himself; circumstances may vary, but nature persists. A French proverb puts it: "Chassez le naturel: il revient au galop." Herein lies the foundation of natural law. Wherever we begin, we come upon our subject.

In any event, it is in Greece that we ordinarily fix the point of departure of the natural law, because the literature and thought of Greece more than those of any other ancient people celebrated the dignity of man. From Greece the idea passed to Rome, where it was taken up by the Jurists. The Romans are usually considered the founders of law, although this is debatable. Science is a formidable instrument because it breaks down almost all simple assumptions. It is true that those which remain are only the more certain; but the average man likes to have a good many convictions, to be sure of almost everything. As one develops the scientific spirit it becomes increasingly apparent that one can be sure of only a few things and must check painstakingly to be sure of them.

I have just spoken of the tradition which makes the Romans the founders of law. Obviously in order to know if the Romans are the founders of law we should first know what law is. This no one knows very clearly. It gives rise to esoteric discussions, of which we have already had an intimation in the first issue of the Natural Law Forum. Every class of specialists concerned with law has its own conception of what law is. The law specialists par excellence, those who are held and hold themselves to have exclusive competence, are the jurists. Even the name they bear indicates that law is regarded as their especial concern. But many others also treat of the law, such as moralists and philosophers. For instance, Kant's conception of law is often spoken of, and Kant was no jurist. Here we encounter a 
phenomenon which the sociology of science ought to study. It has not done so until now, as far as I know, because sociology is still an embryonic science.

Scientific development is achieved in part by the formation of hermetic scientific groups, whose members live by themselves, communicating very little with the outer world and forming among themselves a technical apparatus of ideas and classifications which they are often alone in comprehending. Moreover, many of them are satisfied not to be understood, because that gives them a feeling of being superior to the ordinary run of humanity. This is a moral aspect of the problem. Man is vain, and vanity is a moral defect. And scientists are like other men.

I know that there is a tendency nowadays to react against this specialization and that there are being formed institutes which attempt to synthesize, forums where specialists of different sciences may meet. But the situation is difficult. Since we have been speaking of sociology, let us take sociology as an example. It would seem that of all the sciences, this deals with the subject matter of the broadest interest, and should therefore speak the most ordinary language. Yet the sociological journals abound in articles incomprehensible to the uninitiated reader.

The scientific disciplines, then, are cut off from each other, even when they deal with the same subject matter. They are separated by language, technique, a whole methodology. This difference of technical approach is a product of the development of distinct groups without mutual rapport. This is a human phenomenon, and a fundamental one. The sociologist calls it "vertical stratification," a very simple term in his vocabulary, although quite meaningless to the outsider.

Returning, then, to the subject of law, we are confronted by three or four groups almost completely isolated from one another. First we have the jurists-law teachers, lawyers, and judges; then the moralists, whose concern with another approach to rules of human activity leads them to concern themselves with law; then again the philosophers, who attempt to establish a general synthesis of all departments of knowledge, including, of course, law. Nowadays it is necessary to add to this list the sociologists. They publish studies on the sociology of law, and their law seems very unlike that of the jurists.

For all these groups, a favorite topic is natural law. It should not be surprising, therefore, to find diverse and rather confusing notions on the subject. In this paper will be found general reflections inspired by the reading and thinking I have done on the subject for more than thirty years. There will be few references to individual authors, because we are dealing with ideas that recur constantly from generation to generation. To me it 
seems more useful to seek out solutions than to search for the exact nuance of thought of this man or that. This latter work, moreover, is being adequately carried out by others.

\section{Historical Bagkground}

Tre HISTORY of natural law shows it standing at the junction of law and morality and raising the question of the relation of the two.

From ancient Greece until the nineteenth century, the idea of natural law appears as a river majestic in its course, flowing peacefully in a great valley. Historians think that the idea of natural law goes back to Heraclitus, in the

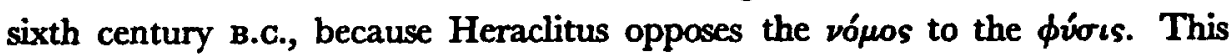
means simply that, discerning order in the universe, he argues that man should in his individual life (morality) and his social life (natural law) make his actions harmonize with that order. In this view, then, natural law is the group of principles which a man ought to observe in his social life.

This idea recurs often in the history of philosophy. Natural law thus conceived is, as it were, the rule of good government. Thus, it is urged chiefly against unjust governments; it is the voice of the opposition, the recourse of the weak. Commonly cited as one of its earliest affirmations, is the tirade of Sophocles' Antigone. Forbidden to bury her brother, she sets in opposition to the tyrant "the divine decrees, the unwritten and immutable laws." "They are neither of today nor of yesterday," she says; "no one knows from what distant past they spring."

Rulers generally do not care for the natural law because it is rarely invoked save in opposing their will. Thus, under the German conception, which triumphed in Nazism, talk of the natural law was suppressed. This conception-that there is no source of law other than the will of the Führer -is traditional in despotic governments. It is told of Haroun al-Rashid, celebrated as the exemplar of Moslem rulers, that on a number of occasions he had brought to him in a sack the head of some man against whom he supposed himself to have cause for complaint. We find another very characteristic example in the story of Esther. Ahasuerus, king of Persia, is angry with his minister Haman, and Haman is put to death. There is no question of juridical forms, of right of defense, or of anything of the kind. The will of the despot is all that is necessary. Moreover, the Biblical narration presents this tradition as normal, and in the case of the Book of Esther, it is described with approval because the story terminates happily for the Jews. This despotism is standard in the Eastern countries of antiquity, and 
in the Moslem world almost down to the present day. Nazism was a return to what has always been done in the Orient; but it seemed monstrous in the West, because we have a different tradition.

To return to Antigone, the laws of which she speaks are clearly moral laws, presented as superior to rulers. Here already a term appears which will be a source of confusion, since the word "law" can be used in either a moral or a juridical sense. We speak of "moral laws" and we speak also of "positive laws" or commands of a ruler. If we add that until recently most juridical laws were traditional laws, not established by a ruler and for the most part unwritten, yet recognized by rulers and taken as a basis for the conduct of government, we can see that the problem is very complicated indeed. This notion of unwritten traditional law persists in the common law system of the Anglo-Saxon countries, and we find traces of it in other systems as well. If we wish to identify law with the expressed will of a lawmaker, this kind of law which is recognized by the ruler but not created by him raises many difficulties. It is on questions like this that specialists devote themselves to subtle intellectual manipulations that give their wit free rein.

Antigone's idea of a natural "law" superior to the positive law reappears throughout Western history. In late antiquity, the Stoics insisted on the idea that men have rights and duties independent of positive laws, that these rights and duties are founded on a justice which governs human relationships, and that positive law must be just if it is to be binding in conscience. Cicero, the chief witness of the Stoic tradition in his time, develops these ideas at considerable length. Thus is formed the notion of natural law, founded not on the opinions or will of men, but on nature, and prevailing over the positive law established by peoples in their institutions. "The greatest of absurdities," says Cicero, "is to regard all the laws or institutions of nations as just." 1 This natural law inheres in us from birth; it can be neither superseded nor annulled. It is to this law that the weak appeal against the injustice of the strong.

It is true that there have always been skeptics who take issue with these principles and admit of no social regulation other than the will of rulers. They are to be found among the sophists, who aroused such indignation in Socrates and Plato. But these skeptics seem to be whimsical men who swim against the stream. Most moralists and jurists adhere to the natural law.

The skeptical tradition reappears in the West after the Renaissance with the advent of the materialist philosophers. In England it is identified

1. De Legibus, 1.1.15. 
with Hobbes, who admits of no foundation for law except the will of the Prince. Because of this theme, this concept of law has been described as a "will theory" of law. It persists through the centuries shifting from Prince to Parliament its focus of arbitrary power and expresses itself in the wellknown adage that "Parliament can do anything it pleases except make a man a woman." It is true that in Western thought this idea must be taken with reservations, because it is offset by a parallel tradition concerning the rights of man, and because no one could imagine Parliament deciding to have half or even a tenth of the English beheaded. Nevertheless, this maxim, like the equally famous "My country, right or wrong," expresses a reaction against the system of natural law, which constantly opposes a moral law to the will of the legislator. A similar current in legal thinking is represented by the German voluntarist theory of law and the state, which developed during the nineteenth century and had its culmination in Nazism.

In our consideration of the natural law, then, we must not forget that there is in Western thought a rival tradition. With this in mind, let us proceed with our review of the natural law tradition.

As we have seen, this tradition was among the ancients a matter of moral principles-of principles governing human conduct. Law is founded on morality; its end is to give force to morality and to help men put moral principles into practice.

This conception naturally became integrated with Christian thought. In the Middle Ages, when the great syntheses of Christian thought appear, natural law takes its place in the moral scheme under the title of justice; it is nothing other than the moral law insofar as it applies to social relations. Thus the distinction between natural law and morality is not very clear-cut, and no great effort is made to point out the difference. St. Thomas' treatise on laws is fairly characteristic, from this point of view: he discerns eternal law, natural law, positive divine law, and positive human law; relates all these laws to a single definition; and emphasizes more what unites them than what distinguishes them.

From this line of thought there developed in the Catholic schools a tradition which related natural law to morality. Catholic treatises on natural law, the work of moralists and theologians, begin with a study of basic or general morality from which natural law is deduced. The latter is often treated under the name of "special morality." The object of law is justice, and positive law has the establishment of justice as its special end. Natural law is that group of general principles we look to in this effort to establish justice.

Let us note in passing that St. Thomas is writing a treatise on leges, 
not a treatise on jus. The natural law he speaks of is purely a body of precepts, without that element of embodiment in a social organization that is essential to law in the juridical sense. But natural law thus understood is no more than moral law considered as emanating from nature-moral law in its broadest aspect. On the other hand, when St. Thomas comes to speak of positive human law he is using law in the juridical sense. In the scheme thus presented, is there a place for a juridical natural law? This would be different from St. Thomas' natural law, which, as we have just seen, is moral and not juridical. Is it, then, some other and more particularized form of morality, perhaps that which deals with the duties of man in society? If so, can it properly be called law at all? To answer this question fully, we must know better than we do what it is that jurists understand by law. Suffice it to say that if law is not the same as morality and natural law is the same as morality, it must follow that natural law is not law, and we should give it a different name.

This would mean that the writers who call natural law "special morality" are right, although this is a rather vague term; there could be other special moralities. Shall we not say instead, "social morality"? Occasionally there is a mention of social morality; but like all such terms, it is used without much attempt at precision. We shall have to return to the problem of terminology. Meanwhile, we can point out the problems as they present themselves.

To return to our historical account, we have seen that natural law, as it persists even today in the tradition handed down from the Middle Ages, is bound up with morality. But with the Renaissance there begins a new tradition which separates the two. This tradition, it seems to me, is the product of a cleavage between the jurists and the moralists.

The doctrine of natural law in the Middle Ages is the work of Catholics, religious and theologians. The moralists who represent the continuing Catholic tradition in our time are similarly churchmen and theologians. On the other hand, Grotius, the seventeenth century Dutchman, whom many writers present as the "father of natural law," is a Protestant, a layman, and a jurist. Pufendorf and Thomasius, the two German jurists usually cited as the seventeenth century heirs of Grotius, are again Protestant laymen. The Reformation has cut Christianity in two; natural law separated from morality is the work of lay Protestant jurists. Theological preoccupations do not concern these men. The intellectual atmosphere in which they live is entirely different from that of the medieval writers. Grotius is not merely the father of natural law; he is also considered the founder of international law. Whereas for the medieval writers natural law is the culmination of a system based on metaphysics, natural law for these men is the point of 
departure of the law of nations. They are interested not in tracing it back to its source, but in developing their doctrines from it.

Thus they do not concern themselves with individual morality. Their interest is in discerning an appropriate foundation for law in the field of international relations, where there is no recognized source of positive law. The only principles that hold their attention are those which can be shown to be at the basis of law, in other words, those which find application in social life. For these men there can be no positive law between states, because the State or Prince has the sovereign power. In its place they put the "law of nations," a group of principles they regard as self-evident and universally admitted.

With the passing of the Middle Ages, jurists can no longer draw inspiration from a view in which natural concepts are integrated into the framework of a Christian community. Left to themselves, they can only resort to moral principles universally admitted or believed by them to be such. They are on the way to that self-evident natural law, written in the hearts of man, which will be professed almost universally until the middle of the nineteenth century. We cannot help seeing a certain naiveté in their insistence that these principles are self-evident. But they are forced to declare them so, because otherwise they would have to prove them. Such proof would be a long and arduous process; and these jurists, as pioneers in the field of international law, have already undertaken the work of several lifetimes.

Why do they not look for a solution in a division of labor whereby specialists in natural law would make their conclusions available to their confreres? Evidently because the only specialists on the subject are Catholic theologians, and the writers of whom we speak are Protestant jurists. Contact has been broken off, even though these men know something of the Catholic tradition and occasionally cite Catholic writers. Moreover, even in the Catholic Church, there is no group which deals with natural law in and for itself. The traditional medieval doctrine is simply the culmination of a system of morality which in turn depends upon a philosophico-theological system. Thus, we are at an impasse. The only practical way to extricate ourselves from it is to assert that we are taking for our basis a self-evident natural law.

I speak here of a "practical" way. This bears on a point which should never be forgotten in the history of philosophy. Sometimes it is thought that the philosopher lives in a state of pure abstraction, wholly given over to his own thought. Actually the philosopher is, like all men, a part of a social milieu, which imposes on him a certain number of assumptions. These he will probably treat as self-evident, feeling that it would be ridiculous to deny 
them. Philosophers are not ordinarily unlike other men, except as regards the precise object of their speculations.

The term "ridiculous" just used indicates that we are dealing with an affective evaluation, a sentiment. It points up the role of sentiment in philosophy. We should like some day to see a psychologist or sociologist publish a factual study of this role; but such a work will not be forthcoming for a long time, for philosophers are generally little interested in psychology and sociology, and psychologists and sociologists know almost nothing of philosophy.

Add to this the fact that all life is built on certain self-evident principles which cannot be put in question without undermining the foundations of life. This fact predisposes our jurists, Grotius and the rest, who need principles on which to build their law of nations, to look for principles they can regard as self-evident. They assure themselves thereby of a solid grounding for their legal doctrines.

But where does one turn to seek these self-evident principles? In the social milieu. Those principles will be declared self-evident which are taken as such in that milieu-as for example, the legitimacy and sacred character of the family, of property, of the State.

At this point scholars begin also to distinguish between natural law and morality, and occasionally to oppose them to each other. When the French Revolutionists proclaim the "Rights of Man," they have no idea of stating principles of morality. None the less they are certainly dealing with natural rights which are independent of and superior to the will of the lawmaker. The idea is like the ancient one, but cut loose from the structure of morality. It is followed up with confused explanations of the difference between natural law and morality.

Until the nineteenth century, the doctrine of natural law develops as if by a process of spontaneous growth. But in the middle of that century comes the eruption of positivism, which claims to do away with natural law. The partisans of natural law are at first disoriented. They continue to insist that their principles are self-evident, and the positivists laugh them to scorn. This is all to the good; it is necessary that the old ramparts fall with the solemn doctors of the old natural law, so that a new school, setting forth a rejuvenated conception, may arise. In the twentieth century we begin again to speak of natural law, but in relatively new terms. Positivism has brought many to one conclusion: natural law is not indisputably self-evident.

The still growing positivist movement in our day finds its chief expression in sociology—not among all sociologists, to be sure, but among those who think that the question of abstract truth is not one with which men can 
profitably concern themselves, and that men should instead be content to study and deal with social phenomena, their origin, development, and results, in order to perfect the techniques of social existence.

With the sociologists we find the same thing we found with the jurists and the moralists-they form a closed corporation. The function of sociology is not to look for philosophical explanations; it is to examine and correlate facts in such a way as to achieve a systematized interpretation of them on the factual level. Since the sociologist lives within this context, conversing on nothing else with his peers, and since his achievements in it afford him deep satisfaction-especially since his point of view is a new one and produces considerations undreamed of in the past-he quite naturally concludes that there are no other considerations to be explored. It is a fairly natural defect of the human mind to suppose that the questions which absorb it are the only important ones, and even, sometimes, that they exhaust reality. This defect springs from the fact that the human mind is not very vigorous. That is the human condition; we have to take it as it is.

It is in the world of the jurists that new conceptions of natural law have developed in this century. The Gatholic theologian-moralists limit themselves in general to the repetition of Scholastic doctrine without any signal effort to discern its significance. The jurists generally know little of the theologian-moralists, and vice versa. Again the closed corporation.

It is true that conditions are tending to change. We have seen that a need for synthesis is making itself felt among the more advanced scholars. A certain number of young jurists are beginning to realize that sociology exists; also a twentieth-century renascence of speculative philosophy is beginning to make its mark here and there. But as René Théry brought out in relation to France in the first number of this ForUm, these are exceptional cases.

Despite the enormous development of the positive sciences, the twentieth century ushers in a rebirth of natural law thinking among the jurists. A growing number of these men come to see that it is impossible to establish law without a certain number of guiding principles. But what can these guiding principles be? They cannot be law itself, if law is to be established from them. What can they be if not the natural law? But how are they different from morality?

We are back to our old question. The first impetus of positivism, and the still active positivist spirit, rendered a service to the natural law by making impossible the provincial attitude of the old-time writers who spoke of a selfevident natural law, embodying all the principles that happened to be accepted by their society. Today the defenders of natural law are more discreet. Some 
are very timid indeed. We shall discuss this later; for the moment let us try to clarify the distinction between law and morality and determine whether natural law is really law.

\section{Natural Law and Morality}

Natural Law finds its embodiment in law. To determine what it is, we must begin with law. Law is the set of rules which govern social organization. This is not offered as a perfect or complete definition; entire books have been devoted to the search for such a definition. This is intended simply as a rule of thumb to orient our discussion. We will not consider here what power can establish law, or what is the boundary between legal and nonlegal rules.

Law is only one of several disciplines which deal with social life. Social philosophy seeks general principles of social life; political science studies the application of these principles; law establishes rules for social life; sociology investigates social phenomena. To give an example: on the subject of labor, social philosophy will provide the principle that human society should be regarded as a community of equals; political science will seek to promote equality in the particular situation by some such device as the organization of labor unions; law will provide for the establishment of such unions, and fix their rights and duties; sociology will study. how they in fact develop and operate.

We say that law fixes rules; at the same time we say that it consists of rules. It has then a series of aspects. The proper and primary meaning of law is existing rules. When we say that law establishes rules, we should really say that men establish rules which are called law. The science which studies law is also called law, but this is a derived meaning. Law is, then, in its basic sense, a social reality, a group of rules governing social life.

Morality, on the other hand, is essentially concerned with the individual. It determines the rules by which he may attain his perfect development or his end. Even when it deals with relations between men, it does so from the point of view of the individual.

Law, which seeks to order society so that men may be happy and may be free to develop, and morality, which sets the direction man's development must take, are constantly meeting and intersecting one another, and borrowing from one another. Both are normative sciences which regulate human activity, and we pass continually from one to the other. Morality forbids lying, and law requires good faith in the formation of contracts. Morality forbids homicide and stealing; law punishes them. Law refuses to sanction 
agreements contrary to good morals; morality determines what agreements are included in this principle. Morality calls for obedience to legitimate governments, and law tells which governments are legitimate. In all these examples, the law involved is the positive law. But what of natural law? Wherein does it partake of the nature of law? Can we find scope for it between law and morality?

All these questions will seem idle to the reader who is not a specialist in the subject. Most people live in a state of intellectual confusion and are quite content to do so. As something of a specialist in the natural law, I am constantly confronted with statements about natural law in the sense of morality. People ask me, for instance, if natural law forbids drunkenness and stealing. The term "natural law" is currently fashionable, especially among Catholics who seek a rallying point against relativism. There are, therefore, many people fond of using it, and they bring it up on any pretext, as other men use the term "sociology."

But it may be useful for some specialists to try to find out what they are talking about. People usually are amused at the spectacle of those Byzantine theologians who were discussing the sex of angels at the moment when the Turks were besieging the city; but the question does have a certain theological importance, and we could equally well admire the detachment of these men of learning who continued to reflect on their problems in the midst of social upheavals. We might also add that most of them would probably not have distinguished themselves in military service. Similarly, boxers and football stars will perhaps dismiss my speculations as insignificant; but, aside from the fact that I can neither box nor play football, it is possible that my modest work may have a social utility as great as theirs.

But to return to our question: to determine whether natural law is really law we must clarify not only the nature of law but also that of morality. Now morality is a rather disconcerting science: on the one hand, it is universal-it applies to all of life; on the other, it lacks a subject matter of its own-we cannot point to acts which are exclusively moral. Actually, morality is the viewing af all acts from a particular perspective, and that perspective is liberty.

Morality deals with the rules for free activity, with the way a man should use his freedom in the governing of his life. An act takes on a moral character when it is freely accomplished. Every free act has a moral character; every act which is not free does not. The problem of free will is thus in a way the key problem of morality.

In the study of morality we encounter the notion of "good," a universal which appears also in other contexts. In addition to "moral good" there 
is "good-in-itself," ontological or metaphysical, which tradition defines as a transcendental property of being, a property possessed by whatever has being. When we call a machine a good machine, or a fruit a good fruit, we are not passing a moral judgment but are using good in this latter sense.

Since morality concerns itself with the free activity of men, moral good is ontological goodness, or good-in-itself, insofar as it becomes an object of man's free activity. A good machine is not a moral value; but as a man applies his free activity to construct such a machine, his act takes on moral value. When we say that morality is objective, we are saying that it applies to an object, that is, that the value of the object, which is not moral, determines the value of the free act, which is moral.

Let us take any technique, for example that of architecture, which makes possible the construction of comfortable, safe, and esthetically pleasing houses. Morality will say that the architect is obliged to respect the rules of this technique. And that principle applies to all human action. Architecture is not morality; but morality commands us to respect the laws of architecture.

Law is a technique also. It establishes rules which enable men to live well together. It is often said that law is the set of rules governing social life; this is usually the first definition which comes to mind. But we can now refine this definition by stating that law is a set of rules for achieving the good of men through society; in other words, for determining what things should be imposed or allowed so that men may find in society the means of development which it is society's object to afford.

There may be mention of "social utility" or "social order" or "common good" as objects of law. But these terms are equivocal. If law aims in the last analysis at the common good, a particular rule of law can still be established for the profit of a group, a class, a family, even an individual. But insofar as there is a rule, the individual will be involved only as representing a category of citizens. For example, the rule of law which applies to the President of the Republic, applies to only one man, but it is at the same time a general rule, applying to every man who finds himself in this position.

Such a rule of law can protect a minority at the expense of the whole community, as is the case when laws are established in favor of a national minority. Similarly, when laws are made for the protection of workers, what inspires them is not the good of the whole community as such but the good of a class and an ideal of justice, which requires the whole community to fulfill its function in regard to this class by safeguarding the rights of the latter; in other words, by permitting it to develop humanly through institutions established for its benefit.

It is true that the good of the whole community is still served indirectly 
in that every member can rely on the community to take those measures most favorable to his own development. Thus, the true common good does not exclude measures whose immediate aim is the good of a particular class.

The good involved here is not a moral good, as can be seen from an example. Catholic moralists, who analyze moral problems more exhaustively than others do, distinguish between the obligation in conscience, which is properly a moral obligation, and the juridical obligation, which is created by law. When, for example, we establish universal suffrage, which is a juridical rule, we may make it simply a right or we may make voting obligatory. But in either case the moralist will ask if the citizen is bound in conscience to vote-if he is morally at fault for not voting. What the jurist asks is whether universal suffrage should be established and how it should be organized. In one way the two perspectives are the same, for the establishment of the juridical rule may be a moral duty for those who govern. But this is no different from the duty of the architect to apply the techniques of architecture.

The distinction between the question of what social rule to establish and the problem of the obligation or licitness of a given action is what makes morality and law two different disciplines, even though the objects of the two are related. We cannot determine juridical good without first ascertaining what man's good is; and since man cannot develop except in society, we cannot know his good without taking into account the social needs of his nature. The moralist, then, should consider social good, and the jurist moral good. But the perspectives of both remain separate, and that difference of perspective results in a difference of mind. The jurist is above all interested in social good, in rules to be observed in view of that good; the moralist is preoccupied with the good of the individual. It is fitting that each should deepen his studies in the direction indicated by his proper discipline, as long as he does not wall himself in, as long as the jurist turns to morality when the idea of moral good becomes relevant, and the moralist turns to law when he comes upon a question of social good.

Natural law, it must be added, has properly an institutional sense. As the group of principles of social order which proceed from the nature of man, it should serve as a foundation for positive law. Since the good it seeks is a social good, it partakes of the nature of law and it is something other than morality.

After all the discussions of our day we begin to realize that the law to which the ancients appealed against unjust enactments of human authority, the one found in Sophocles and Cicero, was not natural law but morality. When Antigone opposes the rights of conscience to the tyrant's decree and 
speaks of eternal laws, she is talking of moral laws. She is no more concerned with natural law than is Maria Goretti when she dies in defense of her chastity. Maria Goretti is a martyr to purity, not to natural law.

The aim of natural law is to seek out those principles stemming from the nature of man which should form the basis of the positive law. To take an example highly relevant to morality, so that we may not shirk our difficulty, let us consider the "right of revolution." May citizens revolt against unjust governments? What means can they or should they employ? The question to which natural law should address itself is whether and in what way this right to revolt is conducive to the social good. This right may be recognized by positive law. Magna Charta in England and several medieval charters in other countries recognized the right of the subject to revolt if the Prince was not fulfilling the obligations he had taken on.

This is a question of social organization, and therefore one of law. Elsewhere morality teaches that one must follow the rules laid down by natural law, just as it teaches that the architect should build well by conforming to the technique of building.

In this question of the right of revolution, we may see very clearly how the two disciplines of morality and law are related. The individual who wonders if he has the right to revolt may consult a moralist. If the unfortunate Antigone had been Catholic, she could have consulted her confessor and thereby received great comfort. But when it comes to ascertaining how the right of revolution occurs in social life-that is, what one might wish to see incorporated into positive law-we are faced with a question of natural law. I have already remarked on this: we are continually passing from law to morality, and vice versa. The two cannot be isolated from one another, for they have many questions in common. But their difference of perspective makes it extremely important not to confuse them.

The most usual. meeting point of natural law and morality is in social morality, the branch of morality which investigates the rights and duties of men qua members of society. In social morality law is constantly referred to; but the aim is still to establish a line of conduct for the individual rather than to determine how society should be organized. Thus, natural law must be distinguished from social morality.

Social philosophy, like morality, might seem at first blush to be identical with natural law. Looking more closely, however, we can see that this is not the case. Social philosophy considers the conditions and the essence of social life as a whole. Law is only one of the manifestations of social life. In a study of social philosophy there might be a chapter devoted to law, to determine the place law has in social life and to study the character of 
law in order to see what differentiates it from other manifestations of social life; but this would be only a chapter. The question of natural law-that is, of the principles which should animate all law-is a particular question which social philosophy may take up but not embrace as its proper object.

Lastly, there is the philosophy of law. It is rather difficult to determine what this is, since writers on the subject are not in agreement. In most cases, however, it consists of a kind of profound reflection-the word philosophy means "profound reflection"- on positive law. Again we are not dealing with natural law. That law remains uniquely itself.

Let us attempt then to understand the words we are using. Morality is the set of rules governing individual conduct; law is the set of rules governing social organization. Social morality is morality because it deals with the conduct of the individual man in society; natural law is law because it deals with natural principles governing social organization. Social philosophy is a profound reflection on social life as a whole; the philosophy of law is a profound reflection on law itself.

\section{The Promulgation of the Natural Law}

The question of promulgation has an important place in law. We can scarcely expect a man to be bound by a law if he has no way of knowing of it; such a law is no law at all. The principle that law should be promulgated is a commonplace of the law, and jurists do not dispute it. Modern legislation under the continental systems fixes carefully the conditions for promulgation. An official gazette is provided for, and a law takes effect only when it has been published there. Common law jurists have paid less attention to the subject of promulgation, but would not deny the basic principle.

But no manner of promulgation will make the well-known principle that "everyone is presumed to know the law" anything but a fiction. Even if we have an official gazette, most citizens will not read it.

Obviously everyone cannot know the whole law; but the law. should be accessible. When a citizen needs to know the law on a given point, it should be possible for him to find it out. If I want to make a will, I can and should find out how to make it validly; and if I wish to drive a car, I can and should learn something of the traffic regulations. When we say that everyone is presumed to know the law, we mean that the law is thus accessible, and that a person affected ought to consult it.

Here I speak of particular dispositions of law rather than of law as a whole. It is the jurists, men who deal with positive law, who have brought out the necessity and importance of promulgation. But is there any pro- 
mulgation of the natural law, or can there be a juridical natural law in the absence of such promulgation?

We can best approach this question, it seems to me, by beginning with the definition of a law given by St. Thomas Aquinas. His system is, to be sure, a theologico-philosophical one; but it does not ignore mundane realities. We shall discover a characteristic example of this in the present case.

When at the beginning of his Treatise on Laws St. Thomas gives a definition he borrows it from Roman law, which he knows through the canonists. Here is his definition, only a part of which concerns us at the moment, but which is good to have in its entirety because we shall have to examine other aspects of it later on. A law is by this definition "an ordinance of reason directed at common good, established and promulgated by competent authority."2

For a law to be a law, then, it must be promulgated. Next St. Thomas defines the different kinds of law and seeks to determine what constitutes promulgation for each. He begins with divine law, which is divine thought as God knows it, and is at the origin of everything; he goes on to discuss natural law, and comes finally to positive divine law and positive human law.

Now the general definition of law which he gives to begin with is inspired by positive human law. We call positive law a law which springs from the will of a person called a lawgiver. It is truly an ordinance of reason, as St. Thomas says, but not a necessary one. Positive law intervenes when reason offers a choice between several alternative solutions. For example, reason offers a choice between freedom of testamentary disposition as it exists in Anglo-Saxon law, and the system of reserve as it exists in Continental European law. What makes one of these systems operative in a given country is the will of the lawgiver.

When it is a matter of divine law and of natural law, however, the problem is entirely different, since these are laws which are not only a work of reason but also govern reason-man's reason in any case; we shall not take up here the question of whether and in what manner these laws are binding on God. The promulgation of a provision of the natural law, and therefore of the whole natural law, presents a question entirely different from that of the promulgation of the positive law:

Let us again recall that in his definition of law St. Thomas draws his inspiration indirectly from Roman law and directly from the canonists, who themselves followed Roman law. Canon law is the very type of positive law, perhaps the purest in existence.

2. Summa Thzologiaz I-II; q. 90. 
We have already noted how law and morality are constantly interwoven. Necessarily, jurists are often concerned with moral questions. As they do not like to be subject to the moralists, however, they often refuse to admit that these are moral questions, but call them by some other name. Thus it is that many French jurists - they are the ones I know best-speak of "equity" as if it were a concept specifically juridical and quite different from what the moralists call justice. Attitudes like this are manifestations of the same professional provincialism I have already discussed; they often obscure what might otherwise be clear.

The interpenetration of law and morality is not the same problem for the canonists that it is for other jurists, since the Church, unlike the state, works out and inculcates its moral commitment primarily through instrumentalities other than law. This security enables the canonist to approach matters of merely ecclesiastical disposition in an atmosphere of insulation from moral concern. It is true that the rules of the canon law are established so that Christians may practice their religion at least to a minimal extent; but these rules provide as they do solely because of the will of the legislator. The obligation to go to Mass on Sunday is an example. The Catholic is under a general moral obligation to attend Mass from time to time, not necessarily every week, and not necessarily on Sunday, although some preference should perhaps be given to that day. But the strict and carefully delimited obligation to go every Sunday, which can be fulfilled on no other day, and in no other way than by physical presence, is an example of pure positive law. The only justification we can give for it is that the legislator wanted it that way. Morality may pose numerous questions concerning this canonical obligation, but the obligation itself is purely juridical, as much so as any example we could find.

Now it is from this context that St. Thomas takes the inspiration for his definition of law with its requirement of promulgation. How can such a definition apply to natural law?

Since St. Thomas includes the principle of promulgation in his definition of law, the natural law must be promulgated. Clearly, it cannot be like a human law read off to the sound of trumpets or printed in an official gazette. For St. Thomas, natural law is that part of the divine law which man knows naturally. Its place in the human consciousness is such that its first principles cannot be effaced. By his God-given nature man has an immediate cognizance of the first principles of action, as he does of the first principles of knowledge.

But as to the extent of this immediate cognizance, St. Thomas is cautious. In a very significant passage he says: "as to general principles, the natural 
law cannot in any way be effaced from the hearts of men at least in its general tenor."3 We can see how he emphasizes the idea that this immediate cognizance applies only to the most general principles. His followers have displayed less caution.

We must remember, however, that when St. Thomas speaks of the promulgation of the natural law he is not particularly concerned with juridical law. When he deals with natural law his interest is chiefly in the first principles of action-that is, of morality. On the other hand, when he approaches positive human law, he sees it clearly as juridical law, and does not seem to be aware of any shift in his thinking. The difficulty of applying to St. Thomas' nonjuridical natural law the general definition of law of which the requirement of promulgation is a part-a jurist's definition as we have seen-is particularly apparent when we consider another point of the same definition: the requirement that a law be "directed at the common good." The common good is a concept in social philosophy; it cannot be inherently the object of the moral law. When I ask myself what I ought to do-the fundamental question of morality-I do not have to refer to the common good except in considering the possible repercussions of the action I contemplate. This consideration, even when it becomes important, is not part of the essence of a moral question; there would still be a moral question without it.

All this highlights the importance of what has been suggested earlier: that we should distinguish between what is of juridical nature in the natural law and the moral law and what is not. But if natural law is of juridical nature, does it not have to be promulgated, since promulgation is itself one of the necessary characteristics of juridical law? Again we must ask, how can it be promulgated?

For St. Thomas the question is not difficult, since his synthesis of thought rests upon God, and God as he conceives Him is the Christian God, the Greator, Providence, the Father. God, in the Christian conception, is a Being eminently active; $\mathrm{He}$ governs all; $\mathrm{He}$ intervenes constantly. The cognitions upon which human action rests are in man because God wills it; they are in some manner infused in man by God. It is the same with the natural law. The promulgation of the natural law is accomplished by God within man's consciousness. We have thus a legislator and true promulgation.

We have seen, however, that the jurists do not much care for this interpretation. In the first issue of this Forum, Professor d'Entrèves remarks that the Thomistic idea of the natural law is difficult to accept nowadays,

3. Id., q. 94, art. 6 . 
because jurists do not like to refer constantly to a philosophical synthesis in which God is made to intervene whenever a law is to be established. I believe that we should go further: this may be especially true of our contemporaries, but jurists have never liked this sort of constant mingling, because as we have seen, their deliberations concerning the positive law require full-time activity and reflection, which they wish to engage in without the distraction of continually recurring philosophical questions. They have the impression that philosophers argue endlessly; they therefore wish to have a juridical natural law beyond the reach of such arguments which they can use as a point of departure. Philosophers find this attitude a bit brusque; but jurists are practitioners, and this is a practical attitude.

But if this natural law is a postulate and does not bear discussion, how can it be promulgated without divine intervention?

This question forces us to reflect more deeply on the very idea of promulgation. We have already observed that promulgation requires not that all men in fact know all laws, but that they be able to know them. Actually, no system of law is explicitly published in its entirety. Indeed, in one such system, the most fundamental rules are not promulgated, in the sense in which legislative enactments are promulgated. I am alluding here to the customary law which is found in the common law of Anglo-Saxon countries. In the countries of Continental Europe, this idea of customary law has passed into the background with the introduction of the Codes, and the establishment of a legislative power whose business it is to make laws. From this comes a tendency to take for granted the idea that there is no law except when the governing power intervenes to establish it. But the law is not thus limited.

In the early conception of law, which has persisted in the common law tradition, the power of the sovereign was one of announcing the law, something quite different from making law. The law was an a priori reality whose origin no one discussed. When there was a private litigation concerning the application of the law, the sovereign intervened to announce the applicable law. In one sense the law was not promulgated. People had a confused idea of what it was, and the intervention of the sovereign made this idea clearer. The sovereign later delegated his powers to tribunals, but in principle it was he who was charged with the mission of announcing the law.

The notion of the promulgation of law is not then as clear in practice as it is in general formulation. Thus we come to feel that the situation of the natural law is not very different from that of the positive law in this regard. We are faced by a group of principles, some relating to natural law, others to positive law, and all at the foundation of social life. 
Again we must distinguish between the principles of natural law and those of positive law. The former are common to all men, because they are to be found wherever human nature appears. The latter pertain to particular human traditions. To sharpen the distinction, it would be desirable to have a science of natural law with a group of specialists entirely devoted to it. As we have seen, there has hitherto been no such group, and the obscurities which complicate the question arise in large part from this lack.

To illustrate what is involved here, let us consider the institution of marriage. If in our time we ask a. Latin what marriage is, he will be apt to answer to the effect that marriage is the institution established by the civil code, in such and such a title. But marriage certainly existed, and existed as a legal institution, before there was a civil code. The civil code codified the principles and may have modified some of them, but it did not create marriage.

Marriage is a traditional institution found, with variations, among all peoples: The question for the student of natural law is whether there are certain conditions which so inhere in the nature of man that they must be incorporated in any system of positive law if the institution of marriage is to be intelligently established under it. But these conditions of the natural order are not all the conditions necessary to the establishment of the institution within a given society. There are conditions peculiar to different societies, and these are embodied in general regulations of positive law the forms of which are determined by tradition. For instance, the legal relations between spouses are arranged differently in the Anglo-Saxon tradition than in the Latin tradition. It is possible that the two traditions are equally conformable to natural law. But how can we determine this without careful study of the natural law?

This brings us back to the observation that natural law is in about the same position as positive law as regards promulgation. The general principles of the positive law are not usually promulgated in the precise sense of promulgation by a lawmaker. In a properly organized society, however, there will be a widespread knowledge of the general principles, and those charged with seeing to the application of the law will have access to its particular dispositions by means of study. Natural law, if it is to have binding force, should be known or knowable in the same way. To admit that it is, we do not need a philosophical synthesis which determines whether the knowledge of natural law is infused in man by God. A man may come to know the natural requirements of social life whenever he reflects upon social life, if he has favorable conditions, and a mind untroubled by prejudice, passion, or an overriding interest in something else. But up to now not much has 
been done in this direction; this is why we have not witnessed the foundation of a science of natural law capable of producing useful results as well as general statements.

\section{Sanction in Natural Law}

Most JURISTs in characterizing law give an important place to sanction. This notion is related to the one which places the origin of law in the command of the one to whom St. Thomas refers in general terms as "having charge of the community," the Republic, the Prince, or the State, depending on the fashion. The sanction of which the jurists speak is one fixed by the law and given effect by such a ruler. This again creates a difficulty for the natural law and a ground for its opponents to deny that it is law.

To explain the idea which jurists hold concerning sanction, it is necessary to recall again what jurists are. The men thus named are those whose central concern is with the courts-professors, lawyers, and judges. When we speak of justice we are particularly concerned with the courts and with those who share in their activity, in other words, with these men.

An outsider observing this group in operation is apt to be rather surprised. Since their function is limited to the application of law, he might have supposed them to be of less importance to the legal system than those who make law. But in our modern world law is made by legislatures whose members are by no means all qualified as jurists. Indeed, jurists tend to have a certain disdain for the members of the legislature and to reproach them for not understanding the law.

The jurist is someone who applies the law and for this purpose seeks to understand it. Since he is not creating the law, he takes it as given. His work is built on this foundation.

Sanction consists of punishing what is against the law, and ignoring social events with which the law does not expressly deal. This last is merely another way of attempting to add force to the express rules of law. In the atmosphere which prevails among jurists, one feels that the only social realities are those regulated by law. One who has seen a little of the world of the jurists observes it to be a tightly closed one. I remember certain English novels which describe the Inns of Court; the "monde du Palais" of the Latin countries is similar. Those who breathe this atmosphere believe that they dominate society. Often they are aware of no social realities except the ones which come before the courts.

In our day, however, this conception of law has waned under the influence of historical and sociological studies and of juridical developments which 
are foreign to civil law and transcend it. Whereas civil law takes up only acts sanctioned by law, sanction does not play the same role in international law and in public law. We realize that a rule of law can be sanctioned only by virtue of another rule of law and that by working back one should be able to arrive at a primary unsanctioned law. Thus, in public law we always arrive at a primary rule which is not juridically sanctioned; thus, also, we admit the existence of an international public law even in the absence of any juridical sanction.

Also, the development of sociology has made us realize that even in civil law sanction is limited by the state of public opinion. We apply laws only insofar as public opinion permits-this is why there are unenforced laws everywhere. Jurists have always been, at least unconsciously, subject to such pressures, although until recently their writings did not give this impression. Moreover, in many fields civil law incorporates general notions such as "good morals," "public order," or "grave injury," the interpretation of which depends on the state of public opinion. Thus, in Franco-Belgian law the Napoleonic code established as a ground for divorce the adultery of the husband aggravated by the keeping of his mistress in the matrimonial home, whereas the wife's adultery was by itself a sufficient ground for divorce. But elsewhere in the code "grave injury" was made a ground for divorce. Times having changed, the courts came to regard the husband's adultery as grave injury. Thus, simple adultery on the part of the husband came to be visited with a sanction under the pressure of public opinion, without any modification of the positive law.

Even if sanction is not a necessary element of law, we may say that the legal system tends to develop it. If we were to personify the legal system we might say that it aspired to sanction. Public law and international law give good illustrations of this.

Ever since the advent of written constitutions in modern times, the earliest example being that of the United States of America, the development of sanctions for political institutions has been one of the chief concerns of their makers. Under older systems of government, the laws concerning the political institutions were the basis for effectuating the sanctions of other laws, but did not themselves carry a sanction. The innovation of providing sanctions for laws of this sort shifts but does not eliminate the incidence of the unsanctioned law. This innovation is nowhere more highly developed than in the system of judicial review of legislative and executive acts as it exists in the United States, but this system itself has no sanction other than public opinion. It is a convention among those on whom it impinges that they will be bound by its determinations. The contempt power, the ostensible 
sanction for judicial acts; could obviously make no more than a token showing against determined opposition from the other branches of government. However far we go in constructing sanctions on our laws, we will eventually come to a point where there is no sanction. Yet the impetus toward sanction is always present.

International law provides an even more striking example. Humanity in our time has arrived at a stage of civilization which makes both possible and necessary the formation of a world society. All jurists agree that such a society cannot be fully effective unless it has some form of sanction at its disposal. Establishing a world society with effective sanctions is surely the gravest problem of our day. It appears, then, that a law does not need sanction to be law, but that it tends toward sanction as a condition of juridical health. Something is lacking in a law with no sanction.

What is the situation with natural law? To begin with, it tends to the sanction provided by the positive law, in that the prescriptions of natural law should ideally be carried out by the positive law. But this does not resolve the problem, because if positive law affords the only sanction for natural law, the latter is then sanctioned only by something other than itself. If we are to treat of natural law in itself we must find if there is a sanction proper to natural law and sharing in its character.

Since the natural law is "natural," imposed upon man's activity, unlike the positive law, which is "artificial," or a product of that activity, we must seek the sanction for natural law in nature, which is its proper domain. Is there a natural sanction for the natural law?

The answer is clear. Since natural law represents the social needs of human nature, the social institutions violative of the natural law will not bear the requisite fruits of human development. This abstract formula means, concretely, that men will remain uncivilized and will not find happiness. If, for example, political society is not organized according to the requirements of nature, it will not provide the citizen with the freedom and security he needs. If the family is not organized according to the requirements of nature, it will not play its proper role in the development of the human personality.

Again, therefore, we find in the natural law the juridical character which we have seen in it throughout these pages. Natural law consists of objective rules for social organization-rules which morality tells us to follow.

\section{Conclusion}

The conclusion to be derived from the foregoing discussion may be stated in a few words. It is this: there is an important place for activities like the 
publication of the Natural Law Forum. A group of specialists working wholeheartedly to determine the nature and scope of natural law in an atmosphere untouched by political or social passion or prejudice will render to humanity an invaluable service.

In these pages we have attempted to determine what natural law is. This idea should furnish a point of departure for subsequent studies. Finding what natural law involves and how positive law accords with it, and discerning how natural law should be translated into positive law may provide subject matter for numerous studies important to the progress of juridical thought.

In concluding this study, however, I ask myself if $I$ am not crying in the wilderness. No one seems to attach significance to a natural law which is anything other than morality. This seems naive to me, but I fear that some will regard my attitude as oversubtle or frivolous. But in my view the fact that natural law has not had a deeper influence than it has until now stems in part from the fact that we have accepted general statements without any attempt to clarify them. Certainly, other factors are at work. There is no necessary equation between clarity and influence; we see that in the field of morality, for instance, great effort has been made to make the principles as clear and precise as possible, but men still violate them. No one would claim, however, that the effort was wasted.

If we were to devote ourselves to the natural law in itself and attempt to clarify its requirements, working with the scientific spirit which is abroad in all disciplines today and which does much to transform human thought and activity, it seems clear that our efforts would contribute much to the welfare of mankind. Such a new undertaking would require generations of gradual development to come to fruition. But when we see the widespread influence in our time of psychology and sociology, sciences with not even a century of effective research behind them, we come to feel that many things can gather force rather quickly. In our world, where we seek for international organization, and multiply meetings calculated to furnish common bases for action, the meeting of a number of specialists dedicated to objective research with only truth as their object would be a phenomenon of great significance.

(Translated by Jeanne C. Rodes) 